\title{
Bringing Ethics into the Classroom: Making a Case for Frameworks, Multiple Perspectives and Narrative Sharing
}

\author{
Sarup R. Mathur ${ }^{1} \&$ Kathleen M. Corley ${ }^{1}$ \\ ${ }^{1}$ Mary Lou Fulton Teachers College, Arizona State University, Tempe, Arizona, USA \\ Correspondence: Sarup R. Mathur, Mary Lou Fulton Teachers College, Arizona State University, Tempe, \\ 85287-1811 Arizona, USA. Tel: 1-480-965-6893.E-mail: sarup.mathur@asu.edu
}

Received: June 4, 2014 Accepted: July 5, 2014 Online Published: August 21, 2014

doi:10.5539/ies.v7n9p136 URL: http://dx.doi.org/10.5539/ies.v7n9p136

\begin{abstract}
This article argues for the need to discuss the topic of ethics in the classroom and presents five frameworks of ethics that have been applied to education. A case analysis used in workshops with educators in the field of Special Education is described, and the benefits of sharing narratives are discussed. The authors offer suggestions, grounded in education literature, for addressing ethics explicitly and for developing a critically reflective perspective toward ethical decision-making.
\end{abstract}

Keywords: ethics, teacher, education, decision making, case analysis, narrative

\section{Introduction}

\subsection{Introduce the Problem}

Many of the concerns confronting teachers in U.S. public schools today, indeed around the globe, require ethical decision making. Teachers may experience tensions between personal beliefs, professional codes of conduct, and moral values when facing ethical issues. In a review analyzing 22 articles from Teaching and Teacher Education, Bullough (2011) found that teachers understood and responded to ethical dilemmas differently and showed different levels of ethical sensitivity. Some made ethical determinations about what was the right thing to do based on their own personal ethics and life experiences, others gave priority to social and institutional norms, and yet still others held a more malleable and thoughtful view attending to a wide range of moral prerogatives (Bullough, 2011). Clearly, teachers need tools to support consideration of multiple perspectives surrounding an issue, tools to facilitate their thinking (Cartledge, Tillman, \& Talbert-Johnson, 2001).

Researchers continue to argue that the teacher education field should approach professional ethics in ways similar to other licensed professions, such as psychology, medicine, and law, with direct teaching on the topic, and explicit statements regarding the rights and privileges of clients, patients, and practitioners (Barret, Casey, Visser, \& Headley, 2012). Unlike these professions where there is more focus on direct instruction on the topic and specialized coursework for teaching ethical decision making, teachers usually engage in an experiential process in which they have to learn to make ethical decisions about instructional practices on their own (Huling \& Resta, 2001; Moir, 2009). For example, preservice teachers in special education learn about the special education law and how it needs to be implemented, but many of them do not engage in discussions of specific ethical concerns that emerge from time to time and challenge their decision making. For example, they need to learn how to evaluate parents' or students' rights in relation to a school policy. In managing student problem behavior, many teachers do not develop awareness about how sometimes their inflexibility and lack of understanding of individual student needs can escalate problem behaviors. They do not learn how to balance flexibility of thinking with consistency in decision making. By engaging in conversations that are structured around various ethical dilemmas, they can learn to use tools to facilitate their thinking and evaluate their own decision making.

Our purpose in writing this article is clear and simple, while our topic, ethics, is in many instances murky and elusive. We aim to explicitly examine implicit notions of ethics, and to highlight existing conceptual frameworks of ethical conduct that have been applied to school settings. We present a fictitious case study we have used in workshops with educators to elicit critical dialogue in a non-threatening context. Our goal in the workshops is for teachers and administrators informed by frameworks of ethics, to hone a critical perspective about their own 
decision making. We describe how case analysis sparks the sharing of personal narratives and explain the process of narrative self-construction. Finally, we offer suggestions for incorporating ethics in professional development for in-service and pre-service teachers.

To begin we briefly describe the current status of ethics education and argue for the need to discuss the topic of ethics in the classroom.

\subsection{Ethics-What and Why}

Etymologically, "ethics" is derived from the Greek word "ethos" which means "character" or "conduct". Ethics is not limited to the actions or behaviors of an individual but includes practices of a profession, an organization, a government agency or a corporation. Philosophers and moral ethicists have historically fallen into two camps when considering the topic of ethics in relation to the individual and society. One group, in the tradition of Hobbes, Locke and Rawls places the individual, independent of society, as more important, while the other group, adherents to the likes of Aristotle, Rousseau, Hegel, Marx and Dewey, consider the society as preeminent to the individual (Graham, 2011; Stefkovich \& O’Brien, 2004; Sullivan, 1986; Warnick \& Silverman, 2011). In a school setting, ethics includes both an individual's actions and the school community's choice to act or govern (Sullivan, 1986).

When deliberating the definition of the term "ethics", individual teachers, parents, and administrators each have a unique view according to their own lived experiences and positioning (Davies \& Harre, 2001). Some rely on words such as "right", "moral", "values"; others have been more inclined towards "policy", "code of conduct", and "professionalism". But all generally seem to agree that educators need to be ethical and that educators should have access to training in understanding the ethical issues involved in decision making. In a review of teacher curricula from 156 colleges and universities, Glanzer and Ream (2007) found that only 9\% of teacher education programs offered ethics courses as program requirements or electives, compared with $71 \%$ of business programs, $60 \%$ of nursing programs, and $51 \%$ of social work programs. Although Glanzer and Ream, warned about generalizing this conclusion beyond the specific sample in their study, their findings suggest ethics is not well emphasized in education programs as compared to many other professional schools, such as social work, counseling, law, and medicine.

Teachers, as many other professionals, often face dilemmas that are complicated and lead to ethical challenges. Although educators (teachers and administrators) in general are supposed to behave ethically, many of them have not had the benefit of specific coursework or training in their teacher preparation programs that would lead to ethical preparedness. Yet ethics, whether named or unnamed, underpin every aspect of school life from decisions about discipline to teacher-talk in the staff room. In our view dialogue about ethics must be pervasive, not reserved for special occasions or framed as a "virtue of the month." All teachers must learn about and commit to instructional and behavioral practices that foster an ethical school culture that embraces and promotes the core values of respect and responsibility, integrity and honesty, and care for self and others.

In the following section, we summarize five conceptual frameworks that have been presented in the literature as tools for understanding the intersection of ethics and education.

\section{Conceptual Frameworks for Ethics in Education}

Five frameworks of ethics have been identified in education: (1) the ethic of care, (2) the ethic of justice, (3) the ethic of critique, (4) the ethic of profession and (5) the ethic of community (Furman, 2004).

(1) The ethic of care is based on the tenet that people are relational, interdependent beings. As infants, humans begin life thoroughly dependent upon the care of others for survival; human babies do not emerge independent and self-sufficient. The ethic of care rejects the idea that the goal of healthy child development is to become independent. Rather, advocates of the ethic of care view people as both relational and capable of autonomy throughout the lifespan (Held, 2006).

(2) The ethic of justice includes both an individual's choice to act justly and the school community's choice to act or govern justly (Sullivan, 1986). The ethic of justice provides a framework for people to solve problems by first establishing what is just and fair for the individual and for the school community.

(3)The ethic of critique has to do with questioning - asking why are things the way they are. One might ask: is bureaucracy, hierarchy, or complacency thwarting progress in a school? To embrace the ethic of critique requires a willingness to reflect upon social justice, upon issues of access, inclusion, and distribution of resources (Giroux, 2003). The ethic of critique illuminates flaws, but typically stops short of offering solutions.

Using the best interest of the child as their touchstone, Shapiro and Stefkovich (2001) merged the three 
aforementioned ethical models of critique, justice and care, to create a new ethical paradigm, (4) the ethic of the profession. The paradigm of the profession focuses on moral aspects and questions specific to schools, much like other professions have done, e.g., medical ethics, legal ethics, and business ethics (Stefkovich \& O'Brien, 2004; Warnick \& Silverman, 2011). In this model, educators are meant to consider their professional principles, codes and standards, such as Council for Exceptional Children (CEC) standards, Common Core standards, and to position the "best interests of the student" as paramount (Shapiro \& Stefkovich, 2001).

Furman (2004) noticed that most of the published work in the ethics literature focusing on educational leadership paid little attention to "the communal processes that are necessary to achieve the moral purposes of schooling in the twenty-first century" (Furman, 2004, p. 220). Missing in this literature, in her opinion, was discussion of community - not in the sense of a kind of micro-society, rather community as the hub of iterative communal processes. Through the process of sharing information, insights, and experiences, the individuals and groups within the community benefit from one another. Furman built a framework with (5) the ethic of community at its center and incorporated the three most widely accepted ethics paradigms-critique, justice, and care, along with Shapiro and Stefkovich's ethic of the profession. Table 1 summarizes these frameworks, their foci, and main ideas they promote with specific guidance for teachers. These frameworks provide multiple ethical lenses through which educators can view the issues they encounter, understand different perspectives and thus take more thoughtful actions.

Table 1. Ethical frameworks in teacher education

\begin{tabular}{|c|c|c|c|}
\hline Framework(s) & Focus & Main Ideas & Role of Teacher \\
\hline Care & $\begin{array}{l}\text { Compassion oriented; values } \\
\text { people over principles }\end{array}$ & $\begin{array}{lr}\text { Caring for } & \text { individuals } \\
\text { promoting } & \text { compassion, } \\
\text { empathy, } & \text { maintaining } \\
\text { relationships and dignity }\end{array}$ & $\begin{array}{l}\text { Meets individual student } \\
\text { needs, and develops positive } \\
\text { relationships that show } \\
\text { nurturing and care for students }\end{array}$ \\
\hline Justice & Rules based decision making & $\begin{array}{l}\text { Promoting fairness by valuing } \\
\text { rights, rules and laws, } \\
\text { supporting equitable treatment }\end{array}$ & $\begin{array}{l}\text { Respects individual students } \\
\text { and deals with them with } \\
\text { fairness, follows due process } \\
\text { to protect civil and human } \\
\text { rights }\end{array}$ \\
\hline Critique & $\begin{array}{l}\text { t can see the } \\
\text { from ethics }\end{array}$ & $\begin{array}{l}\text { Challenging status quo, } \\
\text { initiating social discourse to } \\
\text { confront moral issues and } \\
\text { inequities }\end{array}$ & $\begin{array}{l}\text { Engages in discourses of } \\
\text { questioning the status quo, } \\
\text { analyzes and evaluates who } \\
\text { benefited from the laws, and } \\
\text { demonstrates sensitivity to } \\
\text { inequities }\end{array}$ \\
\hline Profession & $\begin{array}{l}\text { Guiding values within the } \\
\text { teaching profession }\end{array}$ & $\begin{array}{l}\text { Serving best interest of the } \\
\text { student, promoting } \\
\text { professional standards and } \\
\text { decision-making }\end{array}$ & $\begin{array}{l}\text { Uses professional code of } \\
\text { ethics and keeps the student at } \\
\text { the center of decisions }\end{array}$ \\
\hline Community & $\begin{array}{l}\text { Community-based decision } \\
\text { making for the best interest } \\
\text { or greatest good for the local } \\
\text { community }\end{array}$ & $\begin{array}{l}\text { Promoting leadership through } \\
\text { community values, } \\
\text { maintaining relationships and } \\
\text { collaboration, and building } \\
\text { community }\end{array}$ & $\begin{array}{lcr}\text { Concerns with } & \text { community } \\
\text { issues, } & \text { i.e., } & \text { student } \\
\text { achievement } & \text { and } & \text { success for } \\
\text { all } & & \end{array}$ \\
\hline
\end{tabular}

\section{Case Study and Discussion}

We have used the following case study during conference presentations to elicit constructive dialogue around the topic of ethics situated in the context of schooling. In these sessions, rich discussions have emanated from this scenario. The storyline highlights the differing perspectives of a special education teacher and a school principal about the consequences of a student's behavior.

Ms. Green is a caring special education teacher, who just joined Lincoln Elementary School, located in a suburb 
in a southwestern state. She has been assigned to teach a self-contained classroom for second and third grade children identified as having emotional and behavioral disorders (EBD). EBD is one of the special education categories characterized by one or more of the following characteristics: an inability to build or maintain satisfactory interpersonal relationships; an inability to learn; consistent or chronic inappropriate type of behavior or feelings under normal conditions; pervasive mood of unhappiness or depression; physical symptoms or behaviors associated with personal or school problems. A continuum of educational services is necessary to appropriately meet the needs of students who are identified with EBD. Some students with EBD can be served in regular education classrooms with additional supports; others may need one-on-one, personalized programming in a self-contained setting for all or part of their school day.

In Ms. Green's previous job, she taught students with EBD from first through fourth grades. The principal of Lincoln Elementary, Mr. Driscoll, has a very strict view about misbehavior. He has no tolerance for disruptive behavior in classrooms, the cafeteria, the playground, or in the hallways. He believes his primary responsibility as principal is to create a school climate that provides physical safety for all children. Any student who is perceived to be a threat to safety is likely to be removed from the school and sent to an alternative setting (depending on the severity of disruptive behavior). Student behaviors that might lead to immediate suspension or expulsion from Lincoln Elementary include: seriously disrupting classroom instruction; endangering other students, teachers, or school officials; or damaging property. A student who has received a prior suspension, but continues with disruptive behavior, is moved to an alternative setting to avoid further risk. Mr. Driscoll's view of discipline is based on the use of punitive approaches, sometimes without any provision for positive supports.

Ms. Green's view differs significantly from her principal. She had attended a teacher preparation program that focused on positive supports of behavior and differentiated instruction at a recognized university. She considers one-on-one support to be an important component of specialized intervention. She attributes her success with many of her students with EBD to her ability to provide them with individualized attention and interventions when needed.

Sophie, a third grader who recently moved to the area from another state, has only been in Ms. Green's class for three weeks. Sophie gets frustrated with math when she does not understand the directions to complete a task; she shows her frustration by throwing objects. Sophie's mother is concerned about her daughter and repeatedly calls Ms. Green to talk about her child's progress. Sophie's mother is an involved single parent, who is worried about her daughter's adjustment in her new school. She had called the principal's office earlier to complain about the location of the bus stop, and requested the bus to stop closer to her residence. Sophie had attended a Title I school where she was qualified for tutoring after school. Lincoln Elementary School has no funds to provide after-school tutoring. Ms. Green has noticed that Sophie is a little bit anxious and that she gets frustrated easily in math. But if Ms. Green spends an extra 15 minutes either during recess or after school with her, Sophie seems to grasp the concepts and has been making adequate progress. Ms. Green gives Sophie one-on-one attention and helps her understand what was covered during the day and what she needs to do for homework.

One week when Ms. Green was out sick, a substitute teacher took over the class. Not knowing Sophie, the substitute did not fully understand how to deal with her. She did not provide additional supports to Sophie in math. Sophie got frustrated and started throwing her books and papers on the floor. The substitute wrote her up and sent her to the principal's office. Sophie got suspended! The principal, who had been getting upset with what he construed to be complaints from Sophie's Mom, decided he needed to transfer Sophie to an alternative school within the same district. After getting over the flu, Ms. Green came back the following week and learned that Sophie was going to be moved to the alternative school. Ms. Green tried to explain to the principal that she was willing to work with Sophie on a one-on-one basis. The principal did not agree with this option and told Ms. Green that she had other students to focus on. What do you think Ms. Green should have done? How could she better handle this situation?

This case has spurred rich discussion specific to the events described in the text, and perhaps more importantly it has served as a springboard for participants to share and reflect on their own personal narratives. Sophie's story has spawned a range of topics concerning (a) policy issues (zero tolerance for disruptive behavior); (b) the principal's attitude and actions (removal of the student from school to an alternative setting); (c) teacher's job protection (Ms. Green's job security); and (d) concern for the student (what is beneficial for Sophie).

Listening to the varied perspectives of fellow attendees, participants apprehend their own capacity to view a subject through different lenses and from different angles. For example, in one session a participant offered the opinion that Ms. Green needed to follow the school policy and the student Sophie needed to have a negative consequence for her disruptive behavior. A second attendee concurred with this view. Not surprisingly, the two 
participants who articulated this view both worked in administrative roles, and were thus familiar with the responsibility of adhering to established school/district policies. However, a third attendee questioned whether an official policy was actually in place at the school/ district, as the case study had not specified. A number of participants interjected the opinion that whether the principal was following policy or acting on his own accord, Ms. Green might put herself in danger of losing her job by arguing with the principal as he was her boss. Still another participant countered that if Ms. Green succumbed to the principal's decision without arguing for what she believed to be best for the child, she would have to carry the burden of feeling she had failed to support the rights of the student. Each of the diverse views expressed by workshop participants generated lively and productive dialogue, illustrative of the complexity of decision-making. Through discursive collaboration, participants created alternative storylines for the characters.

The stakes are low when people examine cases in which they are not personally involved, so the case study approach provides a good starting point to prompt reflection. In our experience, this case analysis typically segues into the sharing of individual narratives with little or no prompting. In one session, a participant who was a practicing teacher shared a story in which she described herself in a situation very similar to Ms. Green's. In her case, the student was a boy with whom she had established a positive rapport, something not many other teachers had been able to do. The principal wanted the boy removed from this teacher's full inclusion classroom and sent to an alternative school. The teacher recounted how the principal and the school psychologist told her what she should say in the upcoming child-study-team meeting with the boy's mother. The teacher related how she surprised the principal and other school staff, as well herself, when she asserted her view that the boy was making progress in her class, that she wanted to continue working with him, and that she recommended he not be removed to an alternative setting.

Admittedly conference workshops occur in a time and space removed from the school workplace with its competing demands, allegiances, and power hierarchies. Participants may in fact readily share their personal narratives in conference workshops because they are less vulnerable to the censure of superiors and colleagues than they might consider themselves to be in a professional development session conducted at their school or in their district.

Through telling and sharing stories, humans make sense about themselves and the world around them (Mishler, 2006; Seidman, 2013). Sharing stories in a safe setting, away from institutional hierarchy affords the opportunity to delve into complex issues in a low-threat context. People can position themselves and their actions in their own terms. Telling stories allows one to narratively self-construct. Wortham and Gadsden (2006) specified four ways in which narrative positioning occurs and how these principles relate to a narrator's act of self-construction. First, at the most basic level a narrator, by telling an autobiographical story, positions herself as having experienced some event or sequence of events in the past. In this regard, the narrator is in essence saying "this happened and this is what I did, saw, felt..." to the listener (Wortham \& Gadsden, 2006, p. 320). The second tool a narrator employs is "voicing". It is beyond the scope of this article to discuss Bakhtin's construct of voicing in detail (as cited in Ribeiro, 2006). Suffice it to say that the teller of the tale positions herself and the other actors involved in the context of the story, by describing them as certain kinds of people, types that are socially and culturally recognizable to the listener. (The concept is akin to referencing or bringing in the "voices" of others who are outside the immediate story). Thirdly, the narrator evaluates the actions of the people described in the narrative, including the narrator herself, and thereby elaborates her positioning of all involved in the context of the event's unfolding. The fourth way the narrator positions herself is in the moments of the telling itself. The narrator, by choosing to tell a particular story in a particular way to a particular audience positions herself, as well as her interlocutors (the presenters and the other workshop participants). For example, the teacher who related the personal story about standing up for what she considered to be the best interests of the child, positions and constructs herself as a virtuous person, by the act of telling. She also positions the interlocutors as people who would appreciate and not scoff at such a tale (Davies \& Harré, 2001; Schiffrin, 1996; Wortham, 2006; Wortham \& Gadsden, 2006).

We value case analysis and narrative sharing in no small part because we see these activities as participatory and non-didactic. Yet, we are not without opinions. So in the next section we offer a number of suggestions, malleable to each reader's situated context.

\section{Suggestions}

The first step toward making ethical choices in school settings requires awareness of the relationship between actions and ethics. Since ethical issues are complex and individuals bring their own values and prior experiences to each encounter, people must also recognize the need to consider issues and dilemmas from multiple 
perspectives. Such awareness results from engaging in open, honest and explicit discussion.

\subsection{Understanding Ethical Dilemmas}

The case study highlighted the tension between the ethics of care and ethics of profession. Ms. Green was caught between her desire to care for the student and her wish to follow the established school rules and policies for misbehavior. In order to develop common understanding about ethical dilemmas, Shapira-Lishchinsky (2011) suggests building explicit ethical knowledge among teachers, establishing shared ethical guidelines, and embedding dialogue, as a normal course of action in the school culture. When teachers' view themselves as powerless, without adequate tools for making tough decisions, and without administrative support, they find their ability to adhere to their ethical and moral obligations compromised (Shapira-Lishchinsky, 2011). Teachers need strong administrative support and opportunities for professional development and capacity building (Johns, McGrath, \& Mathur, 2008).

Education is more than imparting knowledge of subject matter; education also influences, among other things, the development of ethical decision making. The adults in schools play powerful roles in children's development; these adults-the teachers, administrators, and staff-are the "experts," the guides who can lead students beyond their current state of understanding and mastery to the next, more advanced level, a destination students can reach with assistance (Vygotsky, 1990). Thus, it is incumbent upon the adults in schools to model ethical practices and to help students construct a moral compass guided by fairness, honesty, integrity, civility, compassion, constancy, and responsibility (Campbell, 2008). If students like Sophie receive only punishment (punitive approaches) and confrontation from the principal for breaches of discipline, they are more likely to develop patterns of resistance and oppositional behavior. If Ms. Green, a teacher, cannot articulate her side of an argument, or the principal does not pay heed to what the teacher has to say, Sophie's educational goals (which include her social and emotional development) will continue to be compromised.

In addition to understanding the principles behind behavioral interventions and strategies, educators need to assume responsibility for selecting a specific intervention for implementation. For example, the principal considers himself to be accountable when his decisions are guided by the ethics of profession and justice. He believes he is responsible for providing a safe physical environment (ethics of profession) to all his students and therefore adheres to the policy of zero tolerance for behavioral infractions (ethics of justice). On the other hand, Ms. Green believes in using a continuum of positive supports that includes individualized behavioral interventions (ethics of care) and reinforcement for positive behavior before using punishment. Both the principal and the teacher have reason to believe they are ethical in their own way! Their scenario illustrates the importance of understanding different frameworks of ethics that guide teachers' and administrators' decision making and its short and long-term effects.

\subsection{Talk about Ethical Decision Making}

Some teachers and administrators shy away from discussions of ethics due to a commonly held belief that morality is about values, and not about facts. Debates about opinion and fact, about subjectivity versus objectivity are not unique to our contemporary context; such philosophical questions go far back in time (In Western philosophy such questions have been deliberated in the written record since Plato's dialogues; see T. West \& S. West, 1998). Even though people do not share all the same values, they do share quite a number of basic values-that it is wrong to kill, steal, cheat, or injure another-to name just a few. Sadly, the things people disagree about tend to get all the attention. If there is agreement that education should focus on the development of the whole child, and consensus that every child has a right to an education, there should also be agreement that all students including those with EBD, need access to a positive climate for learning and an opportunity to learn.

So, what does ethical decision making look like when teachers are dealing with problem behaviors? When teachers who use ethical decision making notice a problem behavior, they do not immediately think about removing the problem by removing the student from the instructional context. Teachers grounded in ethics invest in prevention (proactively keeping problems from occurring) and pre-correction (anticipating and correcting in advance prior to the occurrence of the problem behavior); they evaluate if the student needs some signals to engage in positive behavior, additional reminders, prompts and cues. Perhaps a student who is not confident in moving to the next step in learning needs reinforcement for successive approximations and additional prompting. Some students may need to learn self-regulation and anger management skills so they can recognize their own triggers and respond to the early signs of tensions and pressures in socially appropriate ways. Instead of receiving criticisms and ultimatums, many students with challenging behaviors benefit from positive attention and feedback. In some rare instances when disruptive behavior warrants punishment, the ethical teacher uses 
reprimands or response cost (e.g., loss of privilege or points) carefully and judiciously and in conjunction with positive reinforcement (see Table 2 ).

Table 2. A continuum of positive behavior supports

\begin{tabular}{|c|c|}
\hline Steps & Sample Strategies \\
\hline \multirow{6}{*}{ Step 1: Plan for prevention } & Use of tiered 1 approach. \\
\hline & $\begin{array}{l}\text { Use pre-correction (Anticipate what needs to be corrected ahead of } \\
\text { time) }\end{array}$ \\
\hline & Invest in planning, arranging classroom, and scheduling \\
\hline & Establish rules and routines \\
\hline & Establish learning structures: cooperative learning, small groups \\
\hline & Establish contingencies \\
\hline \multirow{5}{*}{ Step 2: Focus on antecedent control } & Prompts and cues for positive behavior \\
\hline & Modeling \\
\hline & Video-modeling \\
\hline & Environmental modifications \\
\hline & Priming \\
\hline \multirow{5}{*}{$\begin{array}{l}\text { Step 3: Focus on teaching adaptive } \\
\text { behaviors }\end{array}$} & Teach social skills \\
\hline & Teach social problem solving \\
\hline & Teach self-control and regulation \\
\hline & Teach study skills \\
\hline & Teach organization skills \\
\hline \multirow{4}{*}{ Step 4: Focus on behavior enhancement } & Implement reinforcement systems \\
\hline & Notice positive behavior \\
\hline & Positive attention \\
\hline & Non-contingent positive attention \\
\hline \multirow{5}{*}{ Step 5: Reduce problem behavior } & Ignoring \\
\hline & Differential reinforcement \\
\hline & Response cost \\
\hline & Timeout \\
\hline & In-school suspension \\
\hline
\end{tabular}

Ethics help teachers identify possible courses of action and assess the value of pursuing these actions. Ethical teachers deliberate on their decisions; they evaluate, review, and reflect on their practices and policies, and refine and improve them accordingly. As they engage in ethical decision making, they learn to view the problem from others' perspective and invite others to give constructive feedback. Professional development opportunities can be structured to assist in building educators' capacity for making ethical decisions.

\subsection{Engage in Ongoing Professional Development}

The purpose of professional development is to support educators in their practice. Therefore the professional learning opportunities offered (or required) for teachers should respond to their needs and suit their contexts. In a collaborative learning environment, teachers can generate narrative cases about the challenges they face related to the ethical dimension of teaching and collectively brainstorm alternatives (Strike \& Soltis, 2004). Participants could be given a list of values and asked to prioritize them by importance to the healthy functioning of the school. They could then be given a list of behaviors and asked to select which behaviors are tied to the values they have chosen. Such an activity would provide teachers an opportunity to have input (and instill ownership) on assorted 
school issues such as confidentiality, protection and proper use of property and assets, policies of discrimination and harassment, and the use of technology and the Internet. Educators, like students, need engagement as well as opportunities for reflection so they can cultivate their own professional learning communities and thus thoughtfully collaborate with colleagues to build a strong ethical culture in their schools.

\subsection{Establish Mentorship Opportunities}

Atjonen (2012) conducted a study with 201 pre-service teachers who were asked to describe, from an ethical viewpoint, both positive and negative mentoring experiences during their student teaching. Results indicated that teacher candidates viewed their mentorship as ethically successful, when they had a mentor who gave them feedback, was student-centered, was fair and just, gave timely advice, gave enough support and listened carefully, was both flexible and demanding, and was a positive person. In an ethically unsuccessful mentorship, they viewed their mentor as someone who was authoritative, refused to give feedback, treated student teachers disrespectfully, was hard and critical, interrupted lessons with insufficient reason, discussed confidential issues with outsiders, and neglected certain basic supervisory tasks. The findings of this study highlight the importance of positive and ethical mentoring of clinical practice. The study indicates the need for mentor teachers to be trained in ethical practices of supervision. Implications of such training go beyond student teaching. All teachers, veteran and new, can benefit from ethical mentoring practices. All can be reflective teachers who continue to develop their decision making skills, professional knowledge, and performance.

\subsection{Including Ethics in the Classroom}

School culture has a powerful effect on the behavior of the members of the school community, including teachers. In a cooperative school context, teachers can have agentive roles identifying situations for which they need to expand ethical understanding in order to bolster their sense of preparedness. They can generate a personal skills inventory and self-determine: Do they find themselves ethically unprepared when they are interacting with students from cultural backgrounds different from their own? Do they find themselves challenged when they are collaborating with their peers? Do they have difficulty engaging with parents, or managing student behavior? To what extent do they demonstrate capacity to act confidently and sensitively? Which aspects of their knowledge and practice need to be strengthened? Similar analysis is needed for student behaviors. Students too can actively participate in generating their own needs assessment for themselves and their school. Where do students see issues of ethics? Are they concerned about cheating, bullying, divisive cliques/gangs, and pressures to skip school, to name a few possibilities?

If ethics is something that is referenced frequently throughout the school - in the classroom, in the staff lounge, in the principals' office, in conversations among teachers, students, and staff, then everyone would have a shared understanding of the ethics valued in the school and be better prepared not only to abide by these ethics, but also to handle problems when they arise.

We support the use of a case analysis framework as a means for generating dialogue about ethics in decision making (Strike \& Soltis, 2004). The case analysis approach does not produce absolute answers; rather it provides a springboard for discourse about alternative possibilities (See Clandinin \& Huber, 2010 for discussion of the affordances of Narrative Inquiry, which is typically a more personalized approach to inquiry than Case Analysis). Case analysis can help increase students' sensitivity to issues, and objectivity in ethical decision making (Richert, 2012; Strike \& Soltis, 2004; Warnick \& Silverman, 2011). Instead of delivering a right or wrong answer, this approach provides a framework for analyzing a situation, understanding the context, considering alternative perspectives surrounding the issue, and building a consensus along ethical dimensions. The process of case analysis is presented in Table 3. 
Table 3. A process of case analysis

\begin{tabular}{ll}
\hline Steps & Questions \\
\hline Fact finding & What are the facts about the case? What we know and don't know? \\
\hline People involved & $\begin{array}{l}\text { Who cares about this case? How facts have been communicated to them? } \\
\text { What are their opinions? How do they see things? }\end{array}$ \\
\hline What is in conflict? & $\begin{array}{l}\text { What are the frameworks that are in conflict with each other? Check out } \\
\text { the values and morals that are in conflict, polices that need to be adhered } \\
\text { to. }\end{array}$ \\
\hline $\begin{array}{l}\text { What are the options? } \\
\text { Consequences? }\end{array}$ & $\begin{array}{l}\text { How would you like to be treated in this conflict? } \\
\text { professional, as a caretaker of students, as a person who is viewed as a } \\
\text { fair person) }\end{array}$ \\
\hline $\begin{array}{l}\text { Do you need to seek expert advice? } \\
\text { Where would you go for that? }\end{array}$ & $\begin{array}{l}\text { Who are your colleagues, mentors, experienced teachers or } \\
\text { administrators who can help? }\end{array}$ \\
\hline $\begin{array}{l}\text { Select the course of action and } \\
\text { follow up }\end{array}$ & $\begin{array}{l}\text { With all the information available, how do you plan to select the best } \\
\text { possible option and continue to monitor your decision? }\end{array}$ \\
\hline $\begin{array}{l}\text { Critique and reflect your } \\
\text { action/decision }\end{array}$ & $\begin{array}{l}\text { Have you noticed any repercussions and negative effects associated with } \\
\text { implementation of your action/decision over time? }\end{array}$ \\
\hline
\end{tabular}

Teaching opportunities can also be created around daily events in schools. For example, when a teacher sees an elementary student having a difficult time maintaining boundaries with another student, the teacher could address the issue with the student individually and ask how he thinks his actions affect the other student, brainstorm desirable alternatives, and assist the student in mapping out a future plan. The teacher could also bring the two students together to talk about the situation and prompt them to articulate their own ideas about what each one could do differently in the future to avoid discord. These examples may seem quite simple, but teaching and practicing ethics begins with a very basic shift from a cycle of action- reaction, to a more recursive pattern that includes reflection and analysis. Such change requires teachers to commit to three steps: to notice, stop and talk. Ultimately, with practice students will become critically-thinking individuals who engage, not just in after-thoughts, but in forethought (Komarraju \& Handelsman, 2012).

\subsection{Teach before Applying Zero Tolerance Consequences}

Some zero tolerance policies produce extreme sanctions (e.g., expulsion or suspension) even for minor infractions (Giersch, 2009). For example, if a student brings a plastic knife to school for lunch, the student's intention may be harmless, but the action may lead to severe punishment. Many examples of such cases exist (Skiba, 2000) in which the enforcement of a zero tolerance policy divorces the infraction from its context. Alternatively, teaching students problem solving, conflict resolution, and self-control strategies before applying punishment, aligns more closely with what schools are meant to be doing-educating. Educators need to understand no action can be assessed devoid of the context in which it is situated.

It is important to teach students why regulations are important, what regulation means, what possible actions might be taken against students if they breach a policy, what some of the long-term consequences resulting from their actions could be, and how students' actions could limit their access to opportunities in the long run. Students should be made aware that society takes away opportunities from those who are arrested, and sent to jail. Behaviors that may appear in their peer circles as "acceptable" or are even supported as "cool" could lead to legal problems someday. It is particularly important for adolescents to learn of societal prohibitions because many adolescents look like adults in size, while they are certainly not adults in terms of development. Schools must provide guidance and teachers must spend time teaching the importance of honesty. Schools should not assume that all students have been taught to place a high value on honesty. Students need to be exposed in schools to discussions about why being honest is valued in society and expected at school. They need to learn why cheating is not a desirable route to success. If schools explicitly taught ways of dealing with ethical issues and provided students plentiful opportunities to consider the consequences of a variety of choices, students would be encouraged to opt for choices that are ethical (Giersch, 2009). 


\subsection{Review Rules and Regulations}

Schools should make the review of regulations an annual practice. It is important to reevaluate the relevance, adequacy and appropriateness of policies, because schools and societies are constantly evolving. New guidelines and procedures may be needed to promote ethical use of media (including, but not limited to texting, Internet use and social media) on and off campus (Campbell, 2008). Guidelines must be developed and communicated to teachers, students and other stakeholders regarding school use of networking tools. Everyone should be involved in discussions about privacy, respect and protection in online environments. Many public schools use learning management systems (LMS); Schools can also use blogs to guide interactive discussions about ethical treatment of oneself and others as well as to send alerts when issues emerge.

Schools should initiate a community dialogue, and invite parents, students, educators to come together to discuss community and school needs, to exchange ideas and share suggestions. If a need emerges for additional policies to respond to new problems in the school, the leadership team should work with community members, apprise them of the situation and take their input when crafting new policies. The school leadership should highlight the goals of any new policies and make clear links to existing policies and procedures, and to the mission of the school and the district.

\section{Conclusion}

Perhaps we should have prefaced this discussion about ethics in schools by clarifying just what the purpose of public education is. Noddings (2003) wondered whether the purpose of schooling has become purely economic: “... to improve the financial condition of individuals and to advance the prosperity of the nation. Hence students should do well on standardized tests, get into good colleges, obtain well-paying jobs, and buy lots of things. Surely there is more to education than this?" (Noddings, 2003, p. 4). It is our view that the purpose of education is to contribute to the person's journey toward responsible selfhood. Schools have an integral role to play in each student's journey to selfhood including those students with EBD. In order to accomplish such noble goals, in addition to being "physically safe", schools must be "emotionally safe places" where caring peer relationships are fostered and supported (e.g., through buddy programs, mentoring, conflict resolution classes); where an ethical culture of community (which includes critique, justice, care, and professionalism) prevails; where students participate in ethical discussions and activities that empower and encourage them to take responsibility for their behavior. Schools need to create environments conducive to developing values of caring and justice rather than only focusing on catching and punishing transgressions or adding surveillance cameras, more security guards, better metal detectors, more locks, shorter lunch periods, more rules.

This article highlighted the need to establish ethical decision making in schools and recommended creating a climate that rouses and inspires the moral and ethical dimensions of living, learning and teaching. Reasons to explicitly discuss ethics in the classroom, as well as challenges to doing so have been noted. The ethics of critique, justice, caring, profession, and community can be tapped as a wellspring for school administrators and teachers who endeavor to create rich ethical environments that nourish the development of the hungry minds and bodies of children throughout their K-12 schooling. Structured professional development opportunities can be organized to help teachers develop an understanding of various frameworks and sharpen their own decision making. Educators need tools to generate and evaluate decisions as they face familiar and unfamiliar ethical dilemmas in their future professional lives.

\section{References}

Atjonen, P. (2012). Student teachers' outlooks upon the ethics of their mentors during teaching practice. $\begin{array}{lllll}\text { Scandinavian Journal of Educational } & \text { Research, } & \text { 56, }\end{array}$ http://dx.doi.org/10.1080/00313831.2011.567395

Barrett, D. E., Casey, E., Visser, R. D., \& Headley, K. N. (2012). How do teachers make judgments about ethical and unethical behaviors? Toward the development of a code of conduct for teachers. Teaching and Teacher Education, 28, 890-898. http://dx.doi.org/10.1016/j.tate.2012.04.003

Bullough, R. V. Jr. (2011). Ethical and moral matters in teaching and teacher education. Teaching and Teacher Education, 27, 21-28. http://dx.doi.org/10.1016/j.tate.2010.09.007

Campbell, E. (2008). Review of the literature: The ethics of teaching as a moral profession. Curriculum Inquiry, $38,357-385$.

Cartledge, G., Tillman, L. C., \& Talbert-Johnson, C. (2001). Professional ethics within the context of student discipline and diversity. Teacher Education and Special Education, 24, 25-37. http://dx.doi.org/ $10.1177 / 088840640102400105$ 
Clandinin, D. J., \& Huber, J. (2010). Narrative inquiry. In B. McGaw, E. Baker, \& P. P. Peterson (Eds.), International encyclopedia of education (3rd ed.). New York, NY: Elsevier.

Davies, B., \& Harré, R. (2001). Positioning: The discursive construction of selves. In M. Wetherell, S. Taylor, \& S. J. Yates (Eds.), Discourse theory and practice: A reader (pp. 261-271). Thousand Oaks, CA: Sage.

Furman, G. (2004). The ethic of community. Journal of Educational Administration, 42, 215-235. http://dx.doi.org/10.1108/09578230410525612

Giersch, J. (2009). Lessons in ethics in American high schools. Public Integrity, 11, 251-260. http://dx.doi.org/ 10.2753/PIN1099-9922110304

Giroux, H. A. (2003). The abandoned generation: Democracy beyond the culture of fear. New York: Palgrave MacMillan.

Glanzer, P. L., \& Ream, T. C. (2007). Has teacher education missed out on the "ethics boom"? A comparative study of ethics requirements and courses in professional majors of Christian colleges and universities. Christian Higher Education, 6, 271-288.

Graham, G. (2011). Theories of ethics: An introduction to moral philosophy with a selection of classic readings. New York, NY: Routledge.

Held, V. (2006). The ethics of care: Personal, political, and global. Oxford; New York: Oxford University Press.

Huling, L., \& Resta, V. (2001). Teacher mentoring as professional development. Washington, DC: ERIC Clearing House on Teaching and Teacher Education No. ED460125.

Johns, B. H., McGrath, M. Z., \& Mathur, S. R. (2008). Ethical dilemmas in education: Standing up for honesty and integrity. Lanham, MD: Rowman and Littlefield Education.

Komarraju, M., \& Handelsman, M. M. (2012). Preparing to teach: Becoming part of an ethical culture. In R. E. Landrum, \& M. A. McCarthy (Eds.), Teaching ethically: Challenges and opportunities. Washington DC: American Psychological Association.

Mishler, E. G. (2006) Narrative and identity: The double arrow of time. In A. DeFina, D. Schiffrin, \& M. Bamberg (Eds.), Discourse and identity (pp. 30-47). Cambridge, UK: Cambridge University Press.

Moir, E. (2009). Accelerating teacher effectiveness: Lessons learned from two decades of new teacher induction. Phi Delta Kappan, 91, 14-21.

Noddings, N. (2003). Happiness and education. New York, NY: Cambridge University Press.

Ribeiro, B. T. (2006). Footing, positioning, voice: Are we talking about the same thing? In A. DeFina, D. Schiffrin, \& M. Bamberg (Eds.), Discourse and identity (pp. 48-82). Cambridge, UK: Cambridge University Press.

Richert, A. E. (2012). What should I do? Confronting dilemmas of teaching in urban schools. New York, NY: Teachers College Press.

Schiffrin, D. (1996). Narrative as self-portrait: Sociolinguistic construction of identity. Language in Society, 25, 167-203. http://dx.doi.org/10.1017/S0047404500020601

Seidman, I. E. (2013). Interviewing as qualitative research: A guide for researchers in education and the social sciences. New York: Teachers College Press.

Shapira-Lishchinsky, O. (2011). Teachers' critical incidents: Ethical dilemmas in teaching practice. Teaching and Teacher Education, 27, 648-656. http://dx.doi.org/10.1016/j.tate.2010.11.003

Shapiro, J. P., \& Stefkovich, J. A. (2001). Ethical leadership and decision-making in education: Applying theoretical perspectives to complex dilemmas. Mahwah, NJ: Lawrence Erlbaum Associates.

Skiba, R. J. (2000). Zero tolerance, zero evidence: An analysis of school disciplinary practice. Indiana Education Policy Center, Policy Research Report, \#SRS2, 1-22. Retrieved from http://www.indiana.edu/ $\sim$ safeschl/ztze.pdf

Stefkovich, J. A., \& O’Brien, G. M. (2004). Best interests of the student: An ethical model. Journal of Educational Administration, 42, 197-214. http://dx.doi.org/10.1108/09578230410525603

Strike, K. A., \& Soltis, J. F. (2004). The ethics of teaching (4th ed). New York, NY: Teachers College Press.

Sullivan, W. M. (1986). Reconstructing public philosophy. Berkeley, CA: University of California Press. 
Vygotsky, L. S. (1990). Imagination and creativity in childhood. Journal of Russian \& East European Psychology, 42(1), 7-97. http://dx.doi.org/10.2753/RPO1061-0405280184

Warnick, B. R., \& Silverman, S. K. (2011). A framework for professional ethics courses in teacher education. Journal of Teacher Education, 62, 273-285. http://dx.doi.org/10.1177/0022487110398002

West, T. R., \& West, S. (1998). Four texts on Socrates: Plato's "Euthyphro," “Apology of Socrates," "Crito," and Aristophanes' "Clouds". Ithaca, NY: Cornell University Press.

Wortham, S. (2006). Learning identity: The joint emergence of social identification and academic learning. New York: Cambridge University Press.

Wortham, S., \& Gadsden, V. (2006). Urban fathers positioning themselves through narrative: An approach to narrative self-construction. In A. De Fina, D. Schiffrin, \& M. Bamberg (Eds.), Discourse and identity (pp. 314-341). New York: Cambridge University Press.

\section{Copyrights}

Copyright for this article is retained by the author(s), with first publication rights granted to the journal.

This is an open-access article distributed under the terms and conditions of the Creative Commons Attribution license (http://creativecommons.org/licenses/by/3.0/). 